\title{
Dinamika Pengaturan Pelaksanaan Dan Pembatalan Putusan Arbitrase Syariah
}

\author{
Habibi \\ habibi@iain-padangsidimpuan.ac.id \\ Fakultas Syariah dan Hukumlnstitut Agama Islam Negeri Padangsidimpuan
}

\begin{abstract}
Abstrak:
Penelitian ini bertujuan untuk mengetahui dan menjelaskan tentang prosedur pelaksanaan dan pembatalan terhadap Putusan BASYARNAS serta kepada Lembaga mana yang kewenangan itu diberikan. Metode penelitian ini adalah kualitatif. Hasil penelitian, menunjukkan bahwa, jika mengacu pada Pasal 61 UU No. 30 Tahun 1999 yang berwenang melaksanakan dan membatalkan Putusan BASYARNAS adalah Pengadilan Negeri. Namun jika didasarkan pada ketentuan Pasal 49 UU No. 3 Tahun 2006 maka yang berwenang melaksanakan dan membatalkan Putusan BASYARNAS adalah Pengadilan Agama.
\end{abstract}

Kata kunci: $\quad$ BASYARNAS, Pelaksanaan, Pembatalan, Pengadilan Agama, Pengadilan Negeri.

\begin{abstract}
:
This study aims to find out and explain the procedures for the implementation and cancellation of the BASYARNAS Decision and to which Institution the authority was granted. The method of this research is qualitative. The results of the study indicate that, if referring to Article 61 of Law No. 30 of 1999 which has the authority to implement and cancel the BASYARNAS Decision is the District Court. But if it is based on the provisions of Article 49 of Law No. 3 of 2006 then the authority to carry out and cancel the BASYARNAS Decision is the Religious Court.
\end{abstract}

Keywords: BASYARNAS, Implementation, Cancellation, Religious Court, District Court. 


\section{Pendahuluan}

Pada dasarnya setiap orang yang berbisnis ataupun melakukan perjanjian dengan orang lain menginginkan hubungan yang baik dan berkelanjutan, tidak seorang pun menghendaki terjadinya sengketa yang dapat menghancurkan hubungan tersebut. Tetapi dalam hubungan bisnis atau suatu perjanjian, masingmasing pihak harus mengantisipasi kemungkinan timbulnya sengketa yang dapat terjadi setiap saat di kemudian hari. Sengketa yang perlu diantisipasi dapat timbul karena perbedaan penafsiran baik mengenai bagaimana cara melaksanakan klausul-klausul perjanjian maupun tentang apa isi dari ketentuanketentuan di dalam perjanjian, ataupun disebabkan hal-hal lainnya. ${ }^{1}$

Terhadap sengketa yang terjadi, pada dasarnya hukum positif di Indonesia telah menyediakan sarana untuk menyelesaikan sengketa para pihak. Hal yang dapat ditempuh oleh para pihak antara lain yaitu: melalui proses Peradilan Umum (litigasi) atau melalui proses di luar peradilan (non litigasi). Kedua lembaga sebagaimana dimaksud adalah pilihan bagi para pihak yang bersengketa untuk menyelesaikan sengketanya.

Arbitrase merupakan salah satu cara penyelesaian sengketa di luar pengadilan yang paling disukai oleh para pengusaha, karena dinilai sebagai cara yang paling serasi dengan kebutuhan dalam dunia bisnis. Bahkan, arbitrase dinilai sebagai suatu pengadilan pengusaha yang independen guna menyelesaikan sengketa yang sesuai dengan keinginan dan kebutuhan mereka. ${ }^{2}$

Di Indonesia dikenal dua lembaga arbitrase yang berfungsi sebagai lembaga penyelesaian sengketa di luar peradilan, yaitu Badan Arbitrase Nasional

${ }^{1}$ Gatot Soemartono, Arbitrase dan Mediasi Di Indonesia (Jakarta: PT Gramedia Pustaka Utama, 2006), hlm. 1.

2Gunawan Widjaja, Arbitrase Vs Pengadilan: Persoalan Kompetensi (Absolut) yang Tidak Pernah Selesai (Jakarta: Kencana, 2008), hlm.70. 
Indonesia selanjutnya disebut (BANI) dan Badan Arbitrase Syariah Nasional selanjutnya disingkat (BASYARNAS). Namun fokus kajian dalam makalah ini hanya akan membahas lembaga arbitrase BASYARNAS.

BASYARNAS adalah perubahan dari nama Badan Arbitrase Muamalat Indonesia selanjutnya disebut dengan (BAMUI) yang merupakan salah satu wujud dari Arbitrase Islam yang pertama kali didirikan di Indonesia. Pendirinya diprakarsai oleh Majelis Ulama Indonesia (MUI), Tanggal 21 Oktober 1993 M. ${ }^{3}$ BAMUI yang pada saat ini dikenal dengan BASYARNAS merupakan bentuk Badan Arbitrase Institusional. ${ }^{4}$ Badan arbitrase ini sengaja didirikan untuk menyelesaikan dan menangani sengketa yang timbul bagi mereka yang menghendaki penyelesaian di luar pengadilan.

Kemudian selama kurang lebih 10 tahun BAMUI menjalankan perannya, maka atas keputusan rapat Dewan Pimpinan Majelis Ulama Indonesia Nomor. Kep-09/MUI/XII/2003 tanggal 24 Desember 2003 nama BAMUI diubah menjadi BASYARNAS sebagai institusi timbang tara yang menangani penyelesaian perselisihan pertikaian di bidang ekonomi syariah. Selain fungsi tersebut di atas, BASYARNAS juga dapat memberikan suatu rekomendasi atau pandangan undang-undang yaitu pandangan yang mengikat tanpa adanya suatu persoalan tertentu yang berkenaan dengan pelaksanaan perjanjian, berasaskan permintaan pihak-pihak yang mengadakan perjanjian untuk penyelesaian. ${ }^{5}$

Sampai saat ini, BASYARNAS masih berada di bawah naungan Undangundang No. 30 Tahun 1999 tentang Arbitrase sebagai payung hukumnya. Mengenai eksekusi putusan yang dikeluarkan oleh BASYARNAS terhadap para

3 Jimmy Joses Sembiring, Cara Menyelesaikan Sengketa di Luar Pengadilan: Negosiasi, Mediasi, Konsiliasi \& Arbitrase (Jakarta: Transmedia Pustaka, 2011), hlm. 121.

${ }^{4}$ Yahya Harahap, Arbitrase (Jakarta: Sinar Grafika, 2004), hIm. 106.

5Rachmadi Usman, Aspek-Aspek Hukum Perbankan Islam di Indonesia (Bandung: PT. Citra Aditya Bakti, 2002), hlm. 105. 
pihak yang tidak secara sukarela menjalankan putusan BASYARNAS mengalami banyak perubahan. Hal ini dikarenakan terdapat intervensi pengadilan negeri dalam pelaksanaan putusan BASYARNAS sebagaimana diatur dalam UndangUndang Arbitrase. Sementara itu, putusan BASYARNAS merupakan putusan atas sengketa ekonomi syariah yang secara substansi dan cara penyelesaiannya berbeda dengan sengketa ekonomi konvensional. ${ }^{6}$

Berdasarkan uraian di atas, dapat diketahui bahwa pelaksanaan putusan maupun pembatalan putusan yang dikeluarkan oleh BASYARNAS memiliki cacatan sejarah yang tidak mulus. Oleh karenanya, fokus kajian dalam tulisan ini adalah memotret dinamika pengaturan pelaksanaan dan pembatalan putusan Arbitrase Syariah yang dikeluarkan oleh BASYARNAS ketika putusan tersebut tidak dilaksanakan secara sukarela oleh pihak yang kalah dalam berperkara.

\section{Pelaksanaan Putusan BASYARNAS}

Arbitrase berasal dari kata arbitrare (Latin) atau arbitrage (Belanda) yang berarti kekuasaan untuk menyelesaikan sesuatu perkara menurut kebijaksanaan. Artinya bahwa penyelesaian sengketa yang dilakukan oleh seorang atau beberapa orang arbiter atas dasar kebijaksanaannya dan para pihak akan tunduk atau mentaati putusan yang diberikan oleh arbiter yang mereka pilih/tunjuk. ${ }^{7}$

Arbitrase adalah cara penyelesaian suatu sengketa perdata di luar peradilan umum yang didasarkan pada perjanjian arbitrase yang dibuat secara

${ }^{6}$ Andi Tenri Soraya, M. Arifin Hamid, dan Juajir Sumardi, "BASYARNAS Sebagai Lembaga Alternatif Penyelesaian Sengketa Bisnis Syariah", Jurnal, Volume 3, Nomor 2, Desember 2014, hlm. 176.

7Wahyu Nugroho, "Efektivitas Penyelesaian Sengketa Ekonomi Syariah di Kantor Pusat Badan Arbitrase Syariah Nasional Jakarta", Jurnal Kewirausahaan, Volume, 3 Nomor. 2, ]uliDesember 2012, hlm. 505. 
tertulis oleh para pihak yang bersengketa. ${ }^{8}$ Jadi, arbitrase merupakan cara penyelesaian suatu sengketa perdata diluar peradilan umum yang didasarkan pada perjanjian arbitrase yang dibuat secara tertulis oleh pihak yang bersengketa, ${ }^{9}$ di mana pihak penyelesaian sengketa tersebut dipilih oleh para pihak yang bersangkutan yang terdiri dari orang-orang yang tidak berkepentingan dengan perkara yang bersangkutan, orang-orang mana akan memeriksa dan memberi putusan terhadap sengketa tersebut. 10

BASYARNAS memiliki kewenangan untuk memberikan suatu rekomendasi atau pendapat hukum, yaitu pendapat hukum yang mengikat tanpa adanya suatu persoalan tertentu yang berkenaan dengan pelaksanaan perjanjian yang sudah barang tentu atas permintaan para pihak yang mengadakan perjanjian untuk diselesaikan. ${ }^{11}$

Menurut BASYARNAS langkah-langkah yang harus ditempuh dalam berperkara adalah terdapat kesamaan secara umum di dalam BANI, namun secara khusus terdapat langkah-langkah tersendiri. berikut:12

a. Persetujuan arbitrase harus dilakukan secara tertulis dan ditandatangani kedua belah pihak.

8Pasal 1 Ayat (1) Undang-Undang Nomor. 30 Tahun 1999 tentang tentang Arbitrase dan Alternatif Penyelesaian Sengketa

9Sophar Maru Hutagalung, Praktek Peradilan Perdata dan Alternatif Penyelesaian Sengketa (Jakarta: Sinar Grafika, 2014), hlm.314.

10Muhibuthawary, "Arbitrase Sebagai Alternatif Penyelesaian Sengketa Ekonomi Syariah Menurut Undang-Undang Nomor 30 Tahun 1999", Asy-Syari'ah, Volume. 16, Nomor. 2, Agustus 2014, hlm. 100.

${ }^{11}$ Andi Tenri Soraya, M. Arifin Hamid, dan Juajir Sumardi, "BASYARNAS Sebagai Lembaga Alternatif Penyelesaian Sengketa Bisnis Syariah ”, hlm. 105.

${ }^{12}$ Ahmad Mujahidin, Prosedur Penyelesaian Sengketa Ekonomi Syariah di Indonesia (Bogor: Ghalia Indonesia, 2010), hlm. 150-151. 
b. Jumlah wasit harus ganjil. Arbiter yang menerima penunjukan tidak boleh mengundurkan diri.

c. Pengajuan permohonan arbitrase harus secara tertulis dan sekurangkurangnya harus memuat:

1) Nama lengkap dan tempat tinggal (tempat kedudukan) kedua belah pihak,

2) Surat uraian singkat tentang duduk sengketa,

3) Apa yang dituntut.

d. Apabila pemohon pada sidang pertama tidak hadir sedangkan ia telah dipanggil sepatutnya, maka permohonan pemohon digugurkan. Bila sidang pertama termohon tidak hadir sedangkan ia telah dipanggil sepatutnya, maka arbiter/majelis arbiter akan memerintahkan agar termohon dipanggil sekali lagi untuk terakhir kali menghadap di muka sidang selambat-lambatnya dalam waktu 14 (empat belas) hari. Apabila termohon masih tetap tidak hadir, maka pemeriksaan akan dilakukan dan permohonan dikabulkan.

e. Putusan harus memuat alasan-alasan kecuali bila disepakati.

f. Keputusan harus diambil berdasarkan kepatutan dan keadilan yang sesuai dengan ketentuan hukum yang berlaku bagi perjanjian yang menimbulkan sengketa yang disepakati para pihak.

g. Putusan bersifat final and binding.

h. Dalam hal putusan tidak ditaati secara sukarela, maka putusan diajukan menurut ketentuan dalam RV.

Peraturan prosedur yang disusun oleh BASYARNAS mengenai pendaftaran, pemeriksaan sampai putusan dan tata biaya tetap mengacu pada Undang-Undang Nomor 30 Tahun 1999 tentang Arbitrase dan Alternatif Penyelesaian Sengketa. ${ }^{13}$ Putusan BASYARNAS bersifat mandiri, final dan

13Mujahidin, Prosedur..., hlm 159. 
mengikat seperti halnya putusan pengadilan yang telah mempunyai kekuatan hukum tetap, jika putusan tersebut diterima dan dilaksanakan secara sukarela oleh pihak yang kalah dalam persidangan.

Akan tetapi, jika pihak yang kalah dalam perkara tidak melaksanakan putusan BASYARNAS dengan sukarela, maka diperlukan peran lembaga pengadilan sebagai pihak yang berwenang melakukan eksekusi putusan yang dikeluarkan oleh BASYARNAS. Adapun lembaga pengadilan yang berwenang melaksanakan eksekusi putusan BASYARNAS saat ini adalah Pengadilan Agama14

Penting diketahui bahwa sebelum diterbitkannya PERMA Nomor 14 Tahun 2016, eksekusi putusan BASYARNAS mengalami beberapa perubahan atau inkonsistensi peraturan, sehingga menimbulkan ketidak pastian hukum dalam masyarakat, khususnya bagi mereka yang berperkara di BASYARNAS.

Jika merujuk kepada ketentuan Pasal 61 Undang-Undang Nomor 30 Tahun 1999 tentang Arbitrase dan Alternatif Penyelesaian Sengketa, maka yang memiliki wewenang untuk melaksanakan eksekusi terhadap putusan BASYARNAS adalah pengadilan negeri. ${ }^{15}$ Namun jika didasarkan pada ketentuan Pasal 49 Undang-Undang Nomor 3 Tahun 2006 tentang Pengadilan Agama, seharusnya yang berwenang melaksanakan putusan BASYARNAS adalah Pengadilan Agama, mengingat sengketa yang ditangani oleh BASYARNAS adalah sengketa ekonomi syariah yang jelas menjadi kewenangan Pengadilan Agama.

Pada tahun 2008, Mahkamah Agung mengeluarkan Surat Edaran (SEMA) Nomor 8 Tahun 2008 tentang Eksekusi Putusan Badan Arbitrase Syariah. SEMA

14Lihat Pasal 13 Ayat (2) Peraturan Mahkamah Agung Nomor 14 Tahun 2016 tentang Tata Cara Penyelesaian Perkara Ekonomi Syariah.

15Lihat Pasal 61 dan Pasal 61 Undang-Undang Nomor 30 Tahun 1999 tentang Arbitrase dan Alternatif Penyelesaian Sengketa. 
ini sejatinya membawa angin segar bagi kepastian Pengadilan Agama sebagai eksekutor atas putusan yang dikeluarkan oleh BASYARANAS. Namun patut disayangkan, karena keberadaan SEMA ini tidak dapat bertahan lama sebagai dasar Pengadilan Agama dalam melaksanakan eksekusi putusan BASYARNAS.

Tahun 2010 Mahkamah Agung kembali mengeluarkan Surat Edaran Nomor 8 Tahun 2010 tentang Penegasan Tidak Berlakunya Surat Edaran Mahkamah Agung Nomor 8 Tahun 2008 tentang Eksekusi Putusan Badan Arbitrase Syriah. Kemunculan SEMA ini bukan tidak beralasan, ketentuan Pasal 59 ayat (3) Undang-Undang Nomor 48 Tahun 2009 tentang Kekuasaan Kehakiman menjadi landasan utama atas terbitnya SEMA Nomor 8 Tahun 2010 yang mencabut SEMA Nomor 8 Tahun 2008 tentang Eksekusi Putusan Badan Arbitrase Syariah. ${ }^{16}$

Ketentuan Pasal 59 ayat (3) Undang-Undang Nomor 48 Tahun 2009 tentang Kekuasaan Kehakiman menjelaskan bahwa dalam hal para pihak tidak melaksanakan putusan arbitrase (termasuk arbitrase syariah) secara sukarela, putusan dilaksanakan berdasarkan perintah Ketua Pengadilan Negeri atas permohonan salah satu pihak yang bersengketa. Maka sejak berlakunya Undang-Undang Nomor 48 Tahun 2009 tentang Kekuasaan Kehakiman ini berlaku, Surat Edaran Mahkamah Agung Nomor 8 Tahun 2008 tentang Eksekusi Putusan Badan Arbitrase Syariah menjadi tidak berlaku lagi, dan secara otomatis eksekusi putusan BASYARNAS menjadi wewenang Pengadilan Negeri. ${ }^{17}$

16Lihat Surat Edaran Mahkamah Agung Nomor 10 Tahun 2010 tentang Penegasan Tidak Berlakunya Surat Edaran Mahkamah Agung Nomor 8 Tahun 2008 tentang Eksekusi Putusan Badan Arbitrase Syariah.

${ }^{17}$ Friska Muthi Wulandari, "Dualisme Peraturan Tentang Kewenangan Pengadilan Terhadap eksekusi Putusan Badan Arbitrase Syariah Nasional (BASYARNAS), Tesis, Universitas Islam Negeri Sunan Kalijaga Yogyakarta, 2017, hlm. 6. 
Tahun 2012, eksekusi putusan BASYARNAS kembali mengundang polemik. Setelah Mahkamah Konstitusi (MK) mengeluarkan putusan Nomor 93/PUU-X/201218 tentang Pengujian Undang-Undang Nomor 21 Tahun 2008 tentang Perbankan Syariah, timbullah polemik terkait pengadilan mana yang berwenang untuk melaksanakan eksekusi putusan BASYARNAS.

Akhirnya, setelah melalui kesenjangan yang cukup lama, pada tahun 2016 Mahkamah Agung kembali memberikan angin segar dengan mengeluarkan Peraturan Mahkamah Agung (PERMA) Nomor 14 Tahun 2016 tentang Tata Cara Penyelesaian Perkara Ekonomi Syariah. PERMA ini memberikan kekuasaan penuh kepada Pengadilan Agama sebagai eksekutor terhadap putusan BASYARNAS yang secara jelas diuraikan dalam Pasal 13 ayat (2) Peraturan Mahkamah Agung Nomor 14 Tahun 2016. Adapun tata cara pelaksanaan putusan BASYARNAS tetap mengacu kepada ketentuan dalam Undang-Undang Nomor 30 Tahun 1999 tentang Arbitrase dan Alternatif Penyelesaian Sengketa. ${ }^{19}$

${ }^{18}$ Pada tahun 2012, terjadi permohonan uji materil Pasal 55 ayat (2) dan ayat (3) UndangUndang Nomor 21 Tahun 2008 tentang Perbankan Syariah terhadap Pasal 28 ayat (1) UndangUndang Dasar Negara Republik Indonesia Tahun 1945 ke Mahkamah Konstitusi oleh Dadang Achmad. Penjelasan Pasal 55 ayat (2) dan ayat (3) ini mengandung kontradiktif yang jelas dimana pada satu sisi secara tegas menyebutkan sedangkan di sisi lain memberi kebebasan untuk memilih, maka lahirlah penafsiran sendiri-sendiri sehingga tidak ada kepastian hukum dan bertentangan dengan Pasal 28D ayat (1) Undang-Undang Dasar Negara Republik Indonesia Tahun 1945. Akhirnya melalui putusannya, MK mengabulkan permohonan uji materil terhadap Pasal 55 ayat (2) Undang-Undang Nomor 21 Tahun 2008 tentang Perbankan Syariah dan menyatakan bahwa penjelasan Pasal 55 ayat (2) Undang-Undang Nomor 21 Tahun 2008 tentang Perbankan Syariah bertentangan dengan UUD NRI 1945 dan tidak mempunyai kekuatan hukum mengikat. Lihat Ridzky Adityanto, "Kedudukan BASYARNAS Dalam Penyelesaian Sengketa Perbankan Syariah (Studi Putusan Mahkamah Konstitusi Nomor 93/PUU-X/2012)", Lambung Mangkurat Law Journal, Volume 1, Issue 2, September 2016, hlm. 144.

19Lihat Pasal 13 ayat (3) Peraturan Mahkamah Agung Nomor 14 Tahun 2016 tentang Tata Cara Penyelesaian Perkara Ekonomi Syariah. 
Hal di atas senafas dengan ketentuan Pasal 55 ayat (1) Undang-undang Nomor 21 Tahun 2008 tentang Perbankan Syariah. Ketentuan tersebut juga sejalan dengan Undang-undang Nomor Nomor 3 Tahun 2006 tenang perubahan atas Undang-undang Nomor 7 Tahun 1989 tentang Peradilan Agama sebagaimana telah diamandemen dengan Undang-undang Nomor 50 Tahun 2009. Sebagaimana ketentuan Pasal 49 disebutkan bahwa peradilan agama mempunyai wewenang memeriksa dan mengadili perkara orang-orang yang beragama Islam di bidang perkawinan, waris, wasiat, hibah, wakaf, zakat, infaq, dan ekonomi syariah. ${ }^{20}$

\section{Pembatalan Putusan BASYARNAS}

Upaya pembatalan bukanlah merupakan upaya banding terhadap putusan arbitrase. Pembatalan merupakan suatu upaya hukum yang luar biasa, atau dengan kata lain Pembatalan putusan adalah upaya hukum yang dapat dilakukan oleh para pihak yang bersangkutan untuk meminta Pengadilan Agama (sesuai dengan Peraturan Mahkamah Agung Nomor 14 Tahun 2016) agar suatu putusan arbitrase dibatalkan, baik terhadap sebagian atau seluruh isi putusan. ${ }^{21}$ Putusan arbitrase umumnya disepakati sebagai putusan yang bersifat final dan binding (mengikat). Oleh karena itu, tanpa alasan yang sangat spesifik, pada prinsipnya suatu pembatalan putusan arbitrase tidak mungkin dipenuhi. Jika kita melihat alasan-alasan pembatalan putusan arbitrase tersebut, maka upaya hukum

20Nunung Rodliyah, Hukum Peradilan Agama (Bandar Lampung: Justice Publisher, 2014), hlm. 31-32.

${ }^{21}$ Munir Fuady, Arbitrase Nasional: Alternatif Penyelesaian Sengketa Bisnis (Bandung: Citra Aditya, 2006), hlm. 10. 
pembatalan merupakan hukum yang memaksa yang tidak dapat dikesampingkan oleh kedua belah pihak. ${ }^{22}$

Dalam proses pembatalan putusan arbitrase, pengadilan tidak berwenang untuk memeriksa pokok perkara. Kewenangan pengadilan terbatas hanya pada kewenangan memeriksa keabsahan prosedur pengambilan putusan arbitrase, antara lain proses pemilihan arbiter hingga pemberlakuan hukum yang dipilih oleh para pihak dalam penyelesaian sengketa. ${ }^{23}$

Putusan BASYARNAS dapat dibatalkan dengan mengajukan secara tertulis permintaan pembatalan putusan dengan didasarkan pada alasan: 24

a. Penunjukan Arbiter tunggal atau majelis tidak sesuai dengan ketentuan yang diatur dalam peraturan prosedur BASYARNAS.

b. Putusan melampaui kewenangan BASYARNAS.

c. Terdapat penyelewengan diantara salah satu anggota Arbiter.

d. Putusan jauh menyimpang dari ketentuan pokok peraturan prosedur BASYARNAS.

e. Putusan tidak memuat dasar-dasar alasan yang menjadi landasan pengambilan putusan tanpa mengurangi ketentuan-ketentuan yang berlaku.

Ketentuan mengenai aturan pelaksanaan dan pembatalan putusan arbitrase dalam Undang-undang Nomor 30 Tahun 1999 tentang Arbitrase dan Alternatif Penyelesaian Sengketa hanya memuat kewenangan Pengadilan

22Susanti Adi Nugroho, Penyelesaian Sengketa Arbitrase dan Penerapan Hukumnya (Jakarta: Prenadamedia Group, 2016), hlm. 264.

23Frans Hendra Winarta, Hukum Penyelesaian Sengketa (Jakarta: Sinar Grafika, 2013), hlm. 85.

${ }^{24}$ Tehedi, "Implementasi Penyelesaian Sengketa Bisnis Syariah di BASYARNAS Perwakilan Yogyakarta (Studi Terhadap Penerapan Sifat Final dan Binding)" Yogyakarta: UIN Sunan Kalijaga, 2013, hlm. 29. 
Negeri, tidak memuat kewenangan Pengadilan Agama, oleh karenanya ada dua pendapat mengenai hal ini, yaitu:

a. Kewenangan tersebut merupakan wewenang Pengadilan Negeri, berdasar Pasal 59, Pasal 61, Pasal 62, Pasal 63, Pasal 64, Pasal 70, Pasal 71, dan Pasal 72 Undang-Undang Nomor. 30 Tahun 1999, sehingga pembatalan putusan Badan Arbitrase Syariah Nasional menjadi kewenangan Pengadilan Negeri.

b. Semua yang berkaitan dengan penyelesaian ekonomi syariah berdasar Pasal 49 huruf (i) merupakan kewenangan Pengadilan Agama, pendapat ini didasarkan kepada asas hukum lex posteriori derogat legi priori dan lex specialis derogat legi generali.

Berdasarkan asas lex posteriori derogat legi priori, peraturan perundangundangan yang lebih baru didahulukan berlakunya daripada peraturan perundang-undangan yang lebih lama/terdahulu. Sedangkan menurut asas lex specialis derogat legi generali, yaitu peraturan perundang-undangan yang sifatnya khusus didahulukan berlakunya daripada peraturan perundangundangan yang sifatnya umum. Kewenangan Pengadilan Agama untuk melaksanakan dan membatalkan putusan BASYARNAS sangatlah tepat sesuai dengan asas hukum lex posteriori derogat legi priori dan lex specialis derogat legi generali. Untuk itu, dasar perluasan kewenangan Peradilan Agama adalah sesuai dengan kebutuhan masyarakat. ${ }^{25}$

Berdasarkan kedua asas hukum sebagaimana dimaksud di atas, maka Undang-undang Nomor 3 Tahun 2006 tentang Peradilan Agama sebagai perubahan atas undang-undang Peradilan Agama yang lama, yang diundangkan

25Ummi Uzma ,"Pelaksanaan Atau Eksekusi Putusan Badan Arbitrase Syariah Nasional (BASYARNAS) Sebagai Kewenangan Pengadilan Agama”, Jurnal Hukum dan Pembangunan, Tahun ke-43 No.3 Juli-September 2013 hlm. 369. 
pada tanggal 20 Maret 2006, merupakan undang-undang terbaru dibanding undang-undang Arbitrase yang diundangkan pada tanggal 12 Agustus 1999 tentang Arbitrase dan Alternatif Penyelesaian Sengketa. Begitu pula, Undangundang Peradilan Agama merupakan Undang-undang bersifat khusus dalam penyelesaian ekonomi syariah, yang sebelumnya merupakan bagian dari kewenangan Pengadilan Negeri/Pengadilan Niaga yang berada dalam lingkup Peradilan Umum.

Hal di atas juga dikuatkan dengan Pasal 13 Ayat (2) Peraturan Mahkamah Agung Nomor 14 tahun 2016, yang menyatakan bahwa pelaksanaan putusan arbitrase syariah dan pembatalannya, dilakukan oleh pengadilan dalam lingkungan Peradilan Agama. Maka, berdasarkan uraian di atas, Pengadilan Agama memiliki wewenang penuh dalam melakukan eksekusi putusan BASYARNAS jika putusan tersebut tidak dilakukan secara suka rela oleh para pihak yang berperkara.

Adapun tata cara permohonan pembatalan putusan arbitrase tetap mengacu pada Undang-undang Nomor 30 Tahun 1999 tentang Arbitrase dan Alternatif Penyelesaian Sengketa., yaitu harus dilakukan secara tertulis dalam waktu paling lama tiga puluh hari terhitung sejak hari penyerahan dan pendaftaran putusan kepada Panitera Pengadilan Agama (sesuai dengan Peraturan Mahkamah Agung Nomor 14 Tahun 2016). Hal ini berarti bahwa putusan arbitrase yang dapat dimohonkan untuk pembatalan adalah putusan arbitrase yang sudah didaftarkan pada pengadilan agama. ${ }^{26}$

Kemudian ketentuan pembatalan putusan arbitrase, terdapat dalam Pasal 70 Undang-undang Nomor 30 Tahun 1999 tentang Arbitrase dan Alternatif

${ }^{26}$ Sudiarto dan Zaeni Asyhdie, Mengenal Arbitrase: Salah Satu Alternatif Penyelesaian Sengketa Bisnis (Jakarta: PT. Raja Grafindo Persada, 2004), hlm.185. 
Penyelesaian Sengketa yang menyatakan bahwa: Terhadap putusan arbitrase para pihak dapat mengajukan permohonan pembatalan apabila putusan tersebut diduga mengandung unsur-unsur, yaitu surat atau dokumen yang diajukan dalam pemeriksaan, setelah putusan dijatuhkan, diakui palsu atau dinyatakan palsu, setelah putusan diambil ditemukan dokumen yang bersifat menentukan yang disembunyikan oleh pihak lawan atau, putusan diambil dari hasil tipu muslihat yang dilakukan oleh salah satu pihak dalam pemeriksaan sengketa.

Permohonan pembatalan putusan arbitrase harus diajukan kepada Ketua Pengadilan Agama (sesuai dengan Peraturan Mahkamah Agung Nomor 14 Tahun 2016) dan harus diajukan secara tertulis dalam waktu paling lama 30 hari terhitung sejak hari penyerahan dan pendaftaran putusan arbitrase kepada Panitera Pengadilan Agama. Apabila Ketua Pengadilan menyatakan bahwa alasan-alasan tersebut tidak terbukti, hal ini dapat digunakan sebagai dasar pertimbangan untuk menolak permohonan pembatalan. ${ }^{27}$ Sedangkan apabila permohonan dikabulkan, Ketua Pengadilan Agama menentukan lebih lanjut akibat pembatalan seluruhnya atau sebagian putusan arbitrase. ${ }^{28}$

Apabila ditelaah ketentuan Pasal 70 Undang-Undang Nomor 30 Tahun 1999 tentang Arbitrase dan Alternatif Penyelesaian Sengketa sebagaimana dimaksud di atas, pembatalan putusan arbiter atau majelis arbitrasi baru akan terjadi apabila diajukan oleh pihak yang merasa dirugikan terhadap putusan tersebut, jadi bukan batal dengan sendirinya tetapi harus berdasarkan inisiatif dari salah satu pihak yang merasa dirugikan. Namun Undang-Undang Arbitrase telah membatasi hak para pihak yang merasa dirugikan untuk mengajukan pembatalan terhadap putusan arbiter tersebut yakni 30 hari terhitung sejak hari

${ }^{27}$ Asyhdie, Mengenal...., hlm.189.

28Sophar Maru Hutagalung, Praktek Peradilan Perdata dan Alternatif Penyelesaian Sengketa, hlm. 321. 
penyerahan dan pendaftaran putusan arbitrase kepada panitera Pengadilan Agama. ${ }^{29}$

\section{Penutup}

Berdasarkan uraian di atas, kewenangan Pengadilan Agama sebagai eksekutor terhadap pelaksaan dan pembatalan putusan BASYARNAS mengalami pasang surut yang disebabkan oleh ketidak konsistenan peraturan yang mendasarinya. Hal ini dapat dilihat dengan terbitnya SEMA Nomor 8 Tahun 2008 tentang Eksekusi Putusan Badan Arbitrase Syariah yang kemudian dihapuskan oleh SEMA Nomor 8 Tahun 2010 tentang Penegasan Tidak Berlakunya SEMA Nomor 8 Tahun 2008. Terbitnya SEMA Nomor 8 Tahun 2010 ini mengembalikan kewenangan pelaksanaan dan pembatalan eksekusi putusan BASYARNAS kepada Pengadilan Negeri.

Selang beberapa tahun kemudian, Pengadilan Agama kembali memegang kewenangan sebagai eksekutor terhadap pelaksanaan dan pembatalan putusan BASYARNAS. Hal ini didasarkan kepada Peraturan Mahkamah Agung Nomor 14 Tahun 2016 tentang Tata Cara Penyelesaian Perkara Ekonomi Syariah. dengan demikian, pelaksanaan dan pembatalan putusan BASYANAS dilakukan oleh Pengadilan Agama.

Namun sebagai langkah antisipasi, sudah selayaknya bagi Pemerintah dan Dewan Perwakilan Rakyat (DPR) untuk membentuk Undang-Undang Arbitrase Syariah atau sekedar melakukan amandemen terhadap UndangUndang Nomor 30 Tahun 1999 tentang Arbitrase dan Alternatif Penyelesaian Sengketa dengan menambahkan ketentuan terkait pelaksanaan dan pembatalan putusan BASYARNAS. Hal ini penting demi tercapainya kepastian hukum dalam masyarakat.

29Susilawetty, Arbitrase dan Penyelesaian Sengketa Ditinjau Dalam Perspektif Peraturan Perundang-Undangan (Jakarta: Gramata Publishing, 2013), hlm. 12. 


\section{Daftar Pustaka}

Adi Nugroho, Susanti, Penyelesaian Sengketa Arbitrase dan Penerapan Hukumnya, Jakarta: Prenadamedia Group, 2016.

Adityanto, Ridzky, "Kedudukan BASYARNAS Dalam Penyelesaian Sengketa Perbankan Syariah (Studi Putusan Mahkamah Konstitusi Nomor 93/PUUX/2012)", Lambung Mangkurat Law Journal, Volume 1, Issue 2, September 2016.

Fuady Munir, Arbitrase Nasional: Alternatif Penyelesaian Sengketa Bisnis, Bandung: Citra Aditya, 2006.

Harahap, Yahya, Arbitrase, Jakarta: Sinar Grafika, 2004.

Hutagalung, Sophar Maru, Praktek Peradilan Perdata dan Alternatif Penyelesaian Sengketa, Jakarta: Sinar Grafika, 2014.

Muhibuthawary, "Arbitrase Sebagai Alternatif Penyelesaian Sengketa Ekonomi Syariah Menurut Undang-Undang Nomor 30 Tahun 1999”, Asy-Syari'ah, Volume. 16, Nomor. 2, Agustus 2014.

Mujahidin, Ahmad, Prosedur Penyelesaian Sengketa Ekonomi Syariah di Indonesia, Bogor: Ghalia Indonesia, 2010.

Nugroho, Wahyu, "Efektivitas Penyelesaian Sengketa Ekonomi Syariah di Kantor Pusat Badan Arbitrase Syariah Nasional Jakarta", ]urnal Kewirausahaan, Volume, 3 Nomor. 2, ]uli-Desember 2012.

Rodliyah, Nunung, Hukum Peradilan Agama, Bandar Lampung: Justice Publisher, 2014. 
Sembiring, Jimmy Joses, Cara Menyelesaikan Sengketa di Luar Pengadilan: Negosiasi, Mediasi, Konsiliasi \& Arbitrase, Jakarta: Transmedia Pustaka, 2011.

Soemartono, Gatot, Arbitrase dan Mediasi Di Indonesia, Jakarta: PT Gramedia Pustaka Utama, 2006

Soraya Andi Tenri, M. Arifin Hamid, dan Juajir Sumardi, "BASYARNAS Sebagai Lembaga Alternatif Penyelesaian Sengketa Bisnis Syariah", Jurnal, Volume 3, Nomor 2, Desember 2014.

Sudiarto dan Asyhdie, Zaeni, Mengenal Arbitrase: Salah Satu Alternatif Penyelesaian Sengketa Bisnis, Jakarta: PT. Raja Grafindo Persada, 2004.

Susilawetty, Arbitrase dan Penyelesaian Sengketa Ditinjau Dalam Perspektif Peraturan Perundang-Undangan, Jakarta: Gramata Publishing, 2013.

Tehedi, "Implementasi Penyelesaian Sengketa Bisnis Syariah di BASYARNAS Perwakilan Yogyakarta (Studi Terhadap Penerapan Sifat Final dan Binding)", Tesis, UIN Sunan Kalijaga Yogyakarta, 2013.

Usman, Rachmadi, Aspek-Aspek Hukum Perbankan Islam di Indonesia, Bandung: PT. Citra Aditya Bakti, 2002.

Uzma, Ummi, "Pelaksanaan Atau Eksekusi Putusan Badan Arbitrase Syariah Nasional (BASYARNAS) Sebagai Kewenangan Pengadilan Agama", Jurnal Hukum dan Pembangunan, Tahun ke-43 No.3 Juli-September 2013.

Widjaja, Gunawan, Arbitrase Vs Pengadilan: Persoalan Kompetensi (Absolut) yang Tidak Pernah Selesai, Jakarta: Kencana, 2008.

Winarta, Frans Hendra, Hukum Penyelesaian Sengketa Jakarta: Sinar Grafika, 2013. 
Wulandari, Friska Muthi, "Dualisme Peraturan Tentang Kewenangan Pengadilan Terhadap eksekusi Putusan Badan Arbitrase Syariah Nasional (BASYARNAS), Tesis, Universitas Islam Negeri Sunan Kalijaga Yogyakarta, 2017.

Undang-undang Nomor 30 Tahun 1999 tentang Arbitrase Dan Alternatif Penyelesaian Sengketa

Undang-undang Nomor 3 Tahun 2006 tentang Perubahan atas Undang-undang Nomor 7 Tahun 1989 tentang Peradilan Agama

Undang-undang Nomor 21 Tahun 2008 tentang Perbankan Syariah

Undang-Undang Nomor 50 Tahun 2009 tentang Peradilan Agama

Undang-Undang Nomor 48 Tahun 2009 tentang Kekuasaan Kehakiman

Peraturan Mahkamah Agung Nomor 14 Tahun 2016 tentang Tata Cara Penyelesaian Perkara Ekonomi Syariah

Surat Edaran Mahkamah Agung Nomor 8 Tahun 2008 tentang Eksekusi Putusan Badan Arbitrase Syariah

Surat Edaran Mahkamah Agung Nomor 8 Tahun 2010 tentang Penegasan Tidak Berlakunya Surat Edaran Mahkamah Agung Nomor 8 Tahun 2008 tentang Eksekusi Putusan Badan Arbitrase Syariah

Putusan Mahkamah Konstitusi Nomor 93/PUU-X/2012 tentang Pengujian Undang-undang Nomor 21 Tahun 2008 tentang Perbankan Syariah 